\title{
Comparison of risk factors that play a role in extra-cranial carotid artery atherosclerosis
}

\section{Ekstrakranyal karotis arter aterosklerozuna neden olan risk faktörlerinin kıyaslanması}

\author{
Ruhan Karahan-Özcan ${ }^{1,2}$, Selen Gür-Özmen ${ }^{3}$
}

Gebze Fatih General Hospital, Department of Neurology, Kocaeli, Turkey

Taksim Research Hospital, Department of Neurology, Istanbul, Turkey

Bahçeşehir University, School of Health Sciences, Department of Neuroscience, Istanbul, Turkey

Corresponding author: Selen Gür-Özmen, MD, Bahçeșehir University, School of Health Sciences, Department of Neuroscience, Istanbul, Turkey

E-mail: drselenozmen@gmail.com

Received/Accepted: June 03, 2019 /December 31, 2019

Conflict of interest: There is not a conflict of interest.

\section{SUMMARY}

Objective: Which risk factors are important in preventing or stabilizin: possible extra-cranial carotid artery stenosis is unclear. We aimed $t_{1}$ investigate risk factors that are associated with extra-cranial carotid arter. stenosis in patients with ischemic stroke.

Method: The records of 215 patients with ischemic stroke who wer admitted to Taksim Research Hospital were screened. Patients who had bee monitored with color Doppler ultrasonography were then categorized on th basis of the degree of stenosis in the carotid artery (group A: $0 \%-49 \%$, grou] B: $50 \%-69 \%$, group $\mathrm{C}$ : $>70 \%$ ). Hypertension, diabetes mellitus hyperlipidemia, cigarette smoking, ischemic heart disease, age, and sex wer evaluated as risk factors. These risk factors were compared among the thre groups by using SPSS version 17.

Results: We found a significant relationship between high mean low-densit. lipoprotein and the severity of carotid stenosis $(p<0.05)$. A simila relationship was found between sex and the severity of carotid stenosi $(\mathrm{p}<0.05)$.

Conclusions: A high low-density lipoprotein level and male sex ar important risk factors for having extra-cranial carotid artery stenosis Therefore, use of more aggressive lipid-lowering treatments, recommendin an appropriate diet, and encouraging physical activity in hyperlipidemic me are important in preventive medical practice.

Keywords: Extra-cranial carotid artery atherosclerosis; low-densit lipoprotein; risk factors
(D) Ruhan Karahan-Özcan
(ID) Selen Gür-Özmen

ORCID IDs of the authors: R.K.Ö. 0000-0002-9386-3977

S.G.Ö. 0000-0001-6233-408X

Amaç: İskemik inmenin en önemli risk faktörlerinden biri olan ekstra-kranyal karotis arter stenozu konusunda birçok çalışma yapılmış olmasına rağmen bu değiştirilebilir risk faktörüne neden olan değişkenlerin hangilerinin primer korumada daha öncelikli olduğu konusu hala çok net değildir. Biz kendi olgu serimizde ekstrakranyal karotis arter stenozuna neden olduğu söylenen risk faktörlerini kıyaslayarak öncelikli tedavi edilmesi gerekenleri saptamay1 amaçladık. Yöntem: İskemik inme nedeniyle Taksim İlkyardım Araştırma Hastanesi’ne başvuran iki yüz on beş hasta renkli Doppler USG ile monitorize edilerek karotis arterlerindeki stenozun derecesine göre üç stenoz grubuna ayrild1 (\%0-29,\% 30-70, $\%>70$ ). Hipertansiyon, Diabetes Mellitus, hiperlipidemi, sigara, iskemik kalp hastalığı, yaş ve cinsiyet risk faktörleri 
olarak değerlendirildi. Bu risk faktörlerinin üç grup arasında önemlilik düzeyinin kıyaslaması SPSS 17 programı kullanılarak yapıldı.

Bulgular: Çalışmamızda ortalama düşük yoğunluklu lipoprotein değeri ve karotid stenozunun ciddiyeti arasında istatistiksel olarak anlamlı bir ilişki saptandı $(\mathrm{p}<0.05)$. Benzer bir ilişki erkek cinsiyet ve karotid stenozunun ciddiyeti arasında da bulundu $(\mathrm{p}<0.05)$. Gruplar arasında yaş, hipertansiyon, diabetes mellitus, sigara kullanımı ve iskemik kalp hastalığı açılarından önemli bir fark bulunmadı.

Sonuç: LDL yüksekliğinin ve erkek cinsiyetin ekstra-kranyal karotis arter stenozunun artışında önemli faktörler olarak ortaya çıkması özellikle LDL yüksekliği olan erkek hastaların daha agresif bir yaklaşımla diyet, fiziksel aktivite arttırma ve kolesterol düşürücü tedavilerinin düzenlenmesi gerekliliğini ön plana çıkartan sonuçlar oldu. Daha geniş hasta serilerinde yapilacak yeni çalışmalarla, değiştirilebilir bir risk faktörü olan ekstra-kranyal karotis arter stenozunu önlemeye yönelik yeni yaklaşımların da ortaya çıkartılması koruyucu hekimlik açısından önemli olacaktır.

Anahtar sözcükler: Ateroskleroz, ekstra-kranyal karotis arter stenozu, erkek cinsiyet, LDL, risk faktörleri

\section{INTRODUCTION}

Innovations that have been made in evaluating acute ischemic stroke in recent years are encouraging regarding a reduction in stroke-related mortality and disabilities in the early period. Evaluating and treating risk factors are important. Most of the risk factors of stroke are related to atherosclerosis ${ }^{1}$. Unmodifiable risk factors in stroke are sex, age, race, and family history. Modifiable risk factors that have been identified for stroke are hypertension, diabetes mellitus (DM), hyperinsulinemia, glucose intolerance, cardiac disease, hyperlipidemia, smoking, asymptomatic carotid artery stenosis, and sickle-cell anemia. Other possible modifiable factors include alcohol consumption, obesity, poor dietary habits, physical activity, hyperhomocysteinemia, drug addiction, hormonal therapy (use of oral contraceptives, hormone replacement therapy), hypercoagulability, fibrinogen, inflammation, and migraines ${ }^{2}$.

The incidence of asymptomatic carotid artery stenosis ( $>50 \%$ ), which is one of the modifiable risk factors of stroke, is $7 \%-10 \%$ in men older than 65 years and $5 \%-7 \%$ in women older than 65 years. In different studies, the annual risk of ipsilateral stroke was reported to be $1 \%-2 \%$. This risk increases in progressive stenosis cases, especially when compared with stable stenosis.

In evaluating disease in carotid arteries, direct noninvasive methods, such as magnetic resonance angiography, computed tomography angiography, and color Doppler ultrasonography, can be used. Invasive methods, such as digital subtraction angiography and conventional angiography, are also used to evaluate disease in carotid arteries ${ }^{3}$.

Among the non-invasive imaging methods, color Doppler ultrasonography is the main diagnostic instrument used for evaluating extra-cranial carotid pathologies because it is easy to apply, has bed-side implementation, requires no equipment, offers detailed information about hemodynamics, as well as morphological information, can be easily tolerated by the patient, and is an affordable method 4,5 .

Age, sex, smoking, hypertension, and high blood cholesterol levels are considered as risk factors for carotid artery stenosis. Besides these factors, obesity, oral contraceptive use (together with smoking, especially an age older than 35 years), the presence of peripheral artery disease, and a high hematocrit are also accepted risk factors ${ }^{6-18}$. Moreover, Phan et al. ${ }^{19}$ emphasized that, independent from conventional vascular risk factors, the structure of the carotid artery might increase the risk of stenosis and early detection of this condition is important for preventive medicine.

The present study aimed to retrospectively analyze risk factors that play an active role in development of symptomatic carotid artery atherosclerosis in patients who have the diagnosis of ischemic stroke caused by large vessel atherosclerosis.

\section{MATERIAL AND METHODS}

\section{Participants and study design}

A total of 215 patients, who were hospitalized in Taksim Research Hospital with the diagnosis of acute ischemic cerebrovascular disease caused by large vessel atherosclerosis were retrospectively studied.

\section{Diagnosis of ischemic stroke}

The diagnosis of ischemic stroke was interpreted as the loss of focal or global cerebral function, which developed immediately and lasted for longer than 24 hours, and it was not attributed to any reason other than vascular reasons. This vascular character was confirmed by using radiological methods. The patients who had undergone cerebral computed tomography in the early period (at the moment of admission), on the $24^{\text {th }}$ hour of admission and after 72 hours were included in the study. 


\section{Exclusion criteria}

Patients who had an intracerebral hematoma, subarachnoid hemorrhage, and intracranial spaceoccupying lesion were excluded. Patients with an akinetic left ventricle, ventricular aneurysm, myocardial infarction earlier than 4 weeks, atrial fibrillation with valvular heart disease, and a prosthetic cardiac valve that was a high-risk source of emboli, as well as patients who were diagnosed with posterior circulation ischemic stroke were not included in the present study. These patients were excluded to be certain about the etiology of ischemic stroke caused by extra-cranial carotid artery stenosis.

\section{Criteria for diagnosis of carotid artery stenosis}

There are different approaches for grading of carotid artery stenosis. In the European Carotid Surgery Trial (ECST) for stenosis grading, the classical angiographic method was preferred. In this method, the diameter of the residual lumen is proportioned to the diameter of the artery at the level of stenosis. In the North American Symptomatic Carotid Endarterectomy Trial (NASCET) and Asymptomatic Carotid Atherosclerosis Study, a modified version of this method was used. In this modified version, grading of stenosis is performed by proportioning the diameter of the residual lumen to the diameter of the artery just after stenosis ${ }^{20,21}$.

To minimize the complexities arising from the different approaches, some researchers consider quantitative values for evaluating stenosis, in addition to narrowing of the lumen. Bluth et al. ${ }^{20,22}$ reported that, at $\geq 80 \%$ narrowing, the peak systolic velocity should be higher than $250 \mathrm{~cm} / \mathrm{s}$, enddiastolic velocity (EDV) should be higher than 100 $\mathrm{cm} / \mathrm{s}$, the systolic velocity ratio should be higher than 3.7 , and the diastolic velocity ratio should be higher than 5.5. In the classification of Moneta et al., which is widely used in Turkey, in stenosis higher than $60 \%$ according to NASCET and $80 \%$ according to ECST, the peak systolic velocity should be higher than $250 \mathrm{~cm} / \mathrm{s}$, EDV should be higher than $100 \mathrm{~cm} / \mathrm{s}$, and the peak systolic velocity ratio should be higher than 4.020 . Authors of previous studies have emphasized that the best parameter in grading stenosis is peak systolic velocity, which has high sensitivity and specificity ${ }^{21}$. We used the classification of Moneta et al. for diagnosing the severity of extra-cranial carotid artery stenosis in our patient group.

\section{Classifying patients by carotid artery stenosis}

The patients were divided into the following three groups on the basis of stenosis grades as determined by colored Doppler ultrasonography (CDUS) using the Toshiba Aplio (7.5-MHz linear probe) device: group A, mild stenosis group (carotid artery stenosis $<30 \%$ ), group B, moderate stenosis (carotid artery stenosis between $30 \%$ and $70 \%$ ), and group C, severe stenosis (carotid artery stenosis $>70 \%$ ). The groups were compared to determine the effect of risk factors by the grade of stenosis.

\section{Covariants}

Hypertension, DM, hyperlipidemia (high-density lipoprotein [HDL], low-density lipoprotein [LDL], total cholesterol, triglycerides) smoking, ischemic heart disease, age, and sex were examined as risk factors in the groups.

\section{Defining risk factors}

Patients who had a diagnosis of hypertension, those who were already taking anti-hypertensive medication, or those who had systolic blood pressure $\geq 140 \mathrm{~mm} \mathrm{Hg}$ or diastolic blood pressure $\geq 90 \mathrm{~mm} \mathrm{Hg}$ (hypertension stage 2) according to the 2017 Guideline for the Prevention, Detection, Evaluation, and Management of High Blood Pressure in Adults ${ }^{23}$ were considered to have hypertension. Patients with fasting blood glucose levels $\geq 126 \mathrm{mg} / \mathrm{dl}$ and randomized blood glucose levels $\geq 200 \mathrm{mg} / \mathrm{dl}$ (ADA 2018) (24) were considered as diabetic. Patients who smoked within the last 1 year were considered as smokers. Patients were diagnosed as having ischemic heart disease by cardiologists in our Department of Internal Diseases on the basis of a history, physical examination, Electrocardiogram data, and transthoracic echocardiography.

\section{Biochemical parameters}

Serum levels of glucose, total cholesterol, triglycerides, and HDL were spectrophotometrically measured by a Roche/Hitachi molecular PP autoanalyzer using an enzymocalorimetric method. LDL and very low-density lipoprotein (VLDL) were calculated using Friedwald's formula. (VLDL = triglycerides $/ 5, \mathrm{LDL}=$ total cholesterol $-\mathrm{HDL}-$ triglycerides/5).

\section{Ethics and protocol approval}

The present study was carried out in accordance with the current Helsinki Convention of the World Medical Association. Approval of all of the patients was obtained to use their medical records in retrospective file scanning. The Ethics Committee of Community Hospitals Association, Turkish Ministry of Health, approved the present study.

\section{Statistical analysis}

The data were analyzed using SPSS for Windows 17.0 statistical package software (SPSS Inc. 2008, Chicago, IL, USA). Qualitative variables were 
analyzed by using Chi-square test and Fisher's exact test. Student's $t$-test for independent samples and Mann-Whitney $U$ test were used to check against the quantitative variables. One-way ANOVA was used to determine if there were any significant differences in variables, such as mean serum LDL levels, age, sex, hypertension, DM, ischemic heart disease, and smoking among the groups.

\section{RESULTS}

The characteristics of the patients involved in the present study are shown in Table 1 . The mean age of the patients was 68.5 years $(\mathrm{SD}= \pm 10.5)$. There was no significant difference in age among the groups. A total of 128 patients were men and 87 were women. There were 85 men and 72 women in group A, 22 men and 9 women in group B, and 21 men and 6 women in group C. Carotid artery stenosis was significantly more frequent in men than in women $(\mathrm{p}<0.05)$.

The mean serum LDL level in Group B was significantly higher than that in group A $(\mathrm{p}<0.001)$. Moreover, the mean serum LDL level in group C was significantly higher than that in groups $\mathrm{B}$ and $\mathrm{A}$ $(\mathrm{p}<0.001)$.

There was no significant difference in the rate of hypertension among the groups. There were no significant differences in the rates of DM and ischemic heart disease among the groups. Furthermore, there was no significant difference in the rate of smoking among the groups.

Table 1: Descriptive and comparative results of the three patient groups

\begin{tabular}{|c|c|c|c|c|}
\hline & \multicolumn{3}{|l|}{ Patient groups } & \multirow{2}{*}{$p$ value } \\
\hline & $\begin{array}{l}\text { Group A } \\
\text { (stenosis <50\%) }\end{array}$ & $\begin{array}{l}\text { Group B } \\
\text { (stenosis 50\%-69\%) }\end{array}$ & $\begin{array}{l}\text { Group C } \\
\text { (stenosis }>70 \% \text { ) }\end{array}$ & \\
\hline Number of subjects (n) & 157 & 31 & 27 & \\
\hline Age (years) & $67.06 \pm 12.5$ & $71.23 \pm 9.8$ & $67.30 \pm 9.6$ & 0.10 \\
\hline Sex, male-female, n (\%) & 85 (54.2)-72 (45.8) & $22(70.9)-9(29.1)$ & 21 (77.7)-6 (22.3) & 0.02 \\
\hline LDL, mean, (SD) & $105 \pm 33$ & $139 \pm 25$ & $167 \pm 24$ & 0.01 \\
\hline HDL, mean, (SD) & $34 \pm 5$ & $35 \pm 4$ & $33 \pm 4$ & 0.50 \\
\hline Hypertension, n (\%) & $114(72.6)$ & $26(83.8)$ & 21 (77) & 0.30 \\
\hline Ischemic heart disease, $\mathrm{n},(\%)$ & $53(33.7)$ & $7(22.5)$ & 9 (33.3) & 0.40 \\
\hline Cigarette smoking, n (\%) & $72(45.8)$ & $15(48.3)$ & $16(59.2)$ & 0.40 \\
\hline Diabetes mellitus, n (\%) & $60(38.2)$ & $13(41.9)$ & $10(37)$ & 0.90 \\
\hline
\end{tabular}

Values are mean \pm standard deviation or $\mathrm{n}(\%)$. n; number, LDL; low-density lipoprotein, HDL; high-density lipoprotein.

\section{DISCUSSION}

Atherosclerosis is the most common reason for stroke with an ischemic nature. Despite numerous studies on atherosclerosis worldwide, the main factor for causing atherosclerosis is still unknown. Since 1992, studies have focused on the regulative mechanism of smooth muscle cell proliferation for playing an important and integral role in atherogenesis, the role of lipids aggravating and provoking atherogenesis, and recently, the role of inflammatory factors ${ }^{25}$.

Various studies have shown that the rate of atherosclerosis is higher in men than in women, this incidence increases after menopause in women ${ }^{12,15}$, 26, 27 . An increase in weight in menopause, a change in lipids, endothelial function disorder, insulin resistance, homocysteine levels, lipoprotein a levels, and an increase in various coagulation factors might play role in atherosclerosis 28 . Fabris et al. ${ }^{13}$ reported that, in 457 patients, the incidence of atherosclerosis in men was higher than that in women in any age group. In our study, carotid artery stenosis was less frequent in women than in men, and there was a significant relationship between the level of carotid artery stenosis and male sex.

Hypertension is an important risk factor in the development of stroke. The relationship between carotid atherosclerosis and hypertension has been emphasized by many researchers $8,9,11,13,29$. However, Handa et al. ${ }^{26}$ did not find any 
relationship between hypertension and carotid atherosclerosis in patients with stroke. These authors attributed this result to the high incidence of hypertension among the population with stroke. Lemne et al. ${ }^{15}$ found no relationship between hypertension and intima-media thickness in the carotid artery. However, Fabris et al. ${ }^{13}$ considered that the hypertension affected intracranial arteries more than extra-cranial vessels. Weber et al. ${ }^{30}$ reported that systolic blood pressure was a strong determinant of early carotid atherosclerosis. Ertan et al. 31 compared hypertension and carotid atherosclerosis in patients with stroke and they found that hypertension was not associated with carotid atherosclerosis. Another study showed that, among female and male patients with non-embolic acute ischemic stroke, an increase in the severity of hypertension was directly proportional to the incidence of stroke in all age categories between 45 and 84 years ${ }^{29}$. An increase in the risk of stroke after the age of 65 years is strongly related to the level of systolic blood pressure ${ }^{29}$. In the present study, there was no significant association between the degree of stenosis and hypertension.

There is an increased tendency for coronary, femoral, and cerebral artery atherosclerosis among patients with diabetes. Research and prospective studies carried out in patients with stroke have shown an increase in the risk of stroke among patients with diabetes. Epidemiological studies have provided a wealth of data indicating that carotid artery atherosclerosis is found in patients with diabetes more frequently than in those without diabetes. Dempsey et al. ${ }^{29}$ found no significant relationship between blood glucose levels and the level of carotid artery stenosis, although Fabris et al. 13 and Bogousslavsky et al. ${ }^{12}$ obtained results proving the opposite. Kalogeropoulou et al. ${ }^{32}$ found that an increase in plasma levels of endothelin- 1 and free radicals and a decrease in prostacyclin levels played a role in development of atherosclerosis in DM. In the present study, there was no significant difference in the rate of DM among the groups.

Smoking accelerates the atherosclerotic process through various mechanisms. Smoking increases aggregation of thrombocytes, decreases the use of myocardial oxygen, and causes hypoxia in vascular structures by an increase in carbon monoxide levels. Furthermore, smoking contributes to development and progression of atheroma plaques in the intima through oxidation of lipids ${ }^{33}$. Smoking, which is an accepted important risk factor for atherosclerotic cardiac and venous diseases, negatively affects the cholesterol profile of adults. This effect appears in the form of an increase in LDL and VLDL cholesterol levels and a decrease in HDL cholesterol levels ${ }^{33,34}$. HDL cholesterol levels of smokers were found to be lower by approximately $10 \%$ compared with non-smoking individuals ${ }^{35}$. A low HDL level is an important risk factor for atherosclerosis. In the present study, there was no significant difference in the rate of smoking among the groups.

The relationship between stroke (especially nonembolic ischemic stroke) and lipid levels in the blood is still unclear. In a meta-analysis of 45 prospective epidemiological studies on 450,000 patients (stroke in 13,000 of them), no significant relationship was found between total serum cholesterol levels and the total incidence of stroke ${ }^{25}$. Even if the relationship between blood lipids and stroke is unclear, serum lipid levels are known to be directly related to extra-cranial carotid artery atherosclerosis and wall thickness ${ }^{36}$. The Asymptomatic Carotid Artery Progression Study showed that 20-40 mg daily use of lovastatin, which is a 3-hydroxy-3-methylglutaryl coenzyme-A (HMG-CoA) reductase inhibitor, decreased extracranial carotid artery intima-media thickening in asymptomatic patients with moderately increased serum LDL cholesterol levels and early carotid artery atherosclerosis ${ }^{25}$. In this previous study, serum cholesterol levels decreased from $156.6 \mathrm{mg} / \mathrm{dl}$ to $113.1 \mathrm{mg} / \mathrm{dl}$ (by $28 \%$ ) in a 6-month period and a significant decrease was found in intima-media thickness in extra-cranial carotid arteries in a 36month period. The Atherosclerosis Risk in Communities study showed that serum total lipid and total cholesterol levels in cases of carotid artery atherosclerosis were significantly higher than those in control cases ${ }^{25}$. A study on patients with familial hypercholesterolemia reported that a decrease in LDL cholesterol levels significantly decreased intima-media thickening related to carotid artery atherosclerosis ${ }^{37}$. Varleta et al. ${ }^{38}$ showed that age, dyslipidemia, systolic blood pressure, and abdominal obesity were predictors of an increase in thickness of the carotid intima-media in a study group of 187 participants. Additionally, Burgess et al. ${ }^{39}$ reported that LDL levels $>100 \mathrm{mg} / \mathrm{dl}$, age, hypertension, and plasma-soluble P-selectin were factors that increased the risk of carotid artery plaques in a study on 597 men. In the present study, no significant difference was found in mean HDL values among the groups. However, the mean serum LDL level was significantly higher in group B than in group A. Moreover, the mean serum LDL level in group $\mathrm{C}$ was significantly higher in group $\mathrm{C}$ than in groups $\mathrm{B}$ and $\mathrm{A}$.

Many studies have shown a close relationship between carotid artery stenosis, ischemic stroke, and ischemic heart disease ${ }^{31}$. Atherosclerosis is a generalized phenomenon, and coronary vessels, 
peripheral arteries, intra-cerebral arteries, and carotid arteries are commonly affected. The general incidence of coronary heart disease among patients with stroke has been reported to vary between $25 \%$ and $48 \%{ }^{40,41}$. The severity of carotid atherosclerosis is thought to be a determinant of ischemic heart disease. Moreover, the most important etiological factor in patients with stroke after coronary artery bypass surgery is carotid disease ${ }^{42}$. In the present study, there was no significant difference in the rate of ischemic heart disease among the groups.

The incidence of stroke increases as age advances. Therefore, age is accepted to be one of the most important risk factors for stroke. A strong relationship has been found between carotid artery atherosclerosis and age $13,15,16,26$. In the present study, there was no significant difference in age among the groups. This may be because almost all of the patients involved in the present study visited the hospital for stroke and the total mean age was also high.

The most interesting finding in the present study is that a high LDL level was a risk factor for carotid artery stenosis. LDL levels can be easily altered through medical treatment and lifestyle changes. The significant relationship between the degree of carotid artery disease and male sex is important because of the necessity of more aggressive treatment of all of the risk factors in male patients. However, we did not find any significant differences in age, the presence of hypertension, the presence of $\mathrm{DM}$, the rate of smoking, and the rate of ischemic heart disease among the groups. These variables have been previously shown to be important risk factors for carotid artery stenosis.

One of the limitations of the present study is that we did not examine abdominal obesity, homocysteine levels, and P-selectin levels, which are other risk factors for carotid artery stenosis. Future studies need to be carried out on a larger number of participants to provide additional data to our study results.

\section{Acknowledgments}

We thank Ellen Knapp, PhD, from Edanz Group (www.edanzediting.com/ac) for editing a draft of this manuscript.

\section{REFERENCES}

1. Gilroy J, Cerebrovascular Diseases. Karabudak R, Basics of Neurology: 1. Edition, Ankara, Güneş kitabevi, 2002; 231.

2. Kumral E, Kumral K. İnme risk faktörleri. Nöropsikiyatri Arşivi 1991;28:55-8.
3. Lannuzi A, Wilcosky T, Mercuri M, Ruba P, Bryan FA, Bond G. Ultrasonographic correlates of carotid atherasclerosis in transient ischemic attack and stroke. Stroke 1995;26:614-9.

4. Erickson SJ, Mewissen MW, Foley WD, Lawson TL, Middleton WD, Quiroz FA, et al. Stenosis of the internal carotid artery: assessment using color Doppler imaging compared with angiography. Am J Roentgenol 1989;152:1299-305.

5. Steinke W, Kloetzch C, Hennerici M. Carotid artery disease assessed by color Doppler flow imaging compared with angiography. Am J Roentgenol 1990;154:1061-8.

6. Barnett HJM. North American Symptomatic Carotid Endarterectomy Symptomatic Trial Collaborators. Beneficial effect of carotid endarterectomy in symptomatic patiensts with high grade stenosis. N Engl J Med 1991;325:445-53.

7. Folsom AR, Eckfeldt JH, Eeitzman S, Ma J, Chambless LE, Barnes RW, et al. Relation of carotid artery wall thickness to diabetes mellitus, fasting glucose and insulin, body size, and physical activity. Stroke 1994;25:66-73.

8. Palomäki H, Kaste M, Raininko R, Salonen O, Juvela S, Sarna S. Risk factors for cervical atherosclerosis in patients with transient ischemic attack or minor ischemic stroke. Stroke 1993;24:970-5.

9. Heiss G, Sharrett AR, Barnes R, Chambless LE, Szkio M, Alzola C. Carotid atherosclerosis measured by mode ultrasound in populations: associations with cardiovascular risk factors in the ARIC study. Am J Epidemiol 1991;134:250-6.

10. Whisnant JP, Homer D, Ingall TJ, Baker HL, O'Fallon WM, Wiebers DO. Duration of cigarette smoking is the strongest predictor of severe extracranial carotid artery atherosclerosis. Stroke 1990;21:707-14.

11. Yasaka M, Yamaguchi $T$, Shichiri $M$. Distribution of atherosclerosis and risk factors in atherotrombotic occlusion. Stroke 1993;24:206-11.

12. Bougusslavsky J, Van Melle G, Regli F. The Lausanne stroke registry. Analysis of 1000 consecutive patients with first stroke. Stroke 1998;19:1083-92.

13. Fabris F, Zanocchi M, Bo M, Fonte G, Poli L, Bergoglio I, et al. Carotid plaque, aging, and risk factors; a study of 457 subjects. Stroke 1994;25:1133-40.

14. Kittner SJ, Sharkness CM, Price TR, Plotnick GD, Dambrosia JM, Wolf PA, et al. Infarcts with a cardiac source of embolism in the NINCDS stroke 
data bank: historical features. Neurology 1990;40:281-4.

15. Lemne C, Jogestrand T, de Faire U. Carotid intima-media thickness and plaque in borderline hypertension. Stroke 1995;26:34-9.

16. Bradley WG, Daroff RB, Fenichel GM, Marsden CD. Neurology in Clinical Practice. 3rd edition, Vol 2. Butterworth-Heinemann, USA, 1991; 907-39.

17. Gorelick PB. The status of alcohol as a risk factor for stroke. Stroke 1989;20:1607-10.

18. Karşıdağ S, Sönmez N, Bakaç G, Ceyhan A, Özer F, Arpacı B, et al. İnme alt gruplarında risk faktörlerinin dağılımı. Klinik Gelişim 1995;8:3497502.

19. Phan TG, Beare RJ, Jolley D, Das G, Ren M, Wong K, et al. Carotid artery anatomy and geometry as risk factors for carotid atherosclerotic disease. Stroke 2012;43:1596-601.

20. Moneta GL, Edwards JM, Chitwood RW. Correlation of North American Symptomatic Carotid Endarterectomy Trial (NASCET) angiographic definition of $\% 70$ to $\% 99$ internal carotid artery stenosis with duplex scaning. J Vasc Surg 1993;17:152-9.

21. The European Carotid Surgery Trialists Collaborative Group. Randomized trial of endarterectomy of recently symptomatic carotid stenosis: final results of the MRC European Carotid Surgery Trials (ECST). Lancet 1998;351:1379-87.

22. Executive Committee for Asymptomatic Carotid Atherosclerosis Study. Endarterectomy for asymptomatic carotid artery stenosis. JAMA 1995;273:1421-8.

23. Guideline for the prevention, detection, evaluation, and management of high blood pressure in adults: a report of the American College of Cardiology/American Heart Association Task Force on clinical practice guidelines. J Am Coll Cardiol 2018;71:e127-248.

24. Classification and diagnosis of diabetes: standards of medical care in diabetes 2018. American Diabetes Association. Diabetes Care 2018;41(Supplement 1):13-27.

25. Barnett HJM, Mohr JP, Stein BM, Yatsu FM. Pathophysiology, diagnosis, and management. In: Stroke. 3rd Edition. Churchill Livingstone, New York, 1998; 7-24.

26. Handa N, Matsumoto M, Maeda H, Hougaku E, Ogawa S, Fukunaga R, et al. Ultrasonic evalution of early carotid atherosclerosis. Stroke 1990;21:156772.
27. Brown PB, Zwiebel WJ, Call GK. Degree of cervical carotid artery stenosis and hemispheric stroke: duplex US findings. Radiology 1989;32:5413.

28. Pines A, Bornstein NM, Shapira I. Menopause and ischaemic stroke: basic, clinical and epidemiological consideration. The role of hormone replacement. Hum Reprod Update 2002;8:161-8.

29. Dempsey RJ, Moore RW. Amount of smoking independently predicts carotid artery atherosclerosis severity. Stroke 1992;23:693-6.

30. Weber F. Risk factors for subclinical carotid atherosclerosis in healthy men. Neurology 2002;59:524-8.

31. Ertan NS, Karşıdağ S, DuranC, Özer F, Arpacı B. Karotis aterosklerozu gelişmesinde etkili risk faktörleri. Uludağ Üniversitesi Tıp Fakültesi Dergisi 2003;29:19-24.

32. Kalogeropoulou K, Mortzos G, Migdalis I, Velentzas C, Mikhailidis DP, Georgiadis E, et al. Carotid atherosclerosis in type 2 diabetes mellitus: potential role of endothelin-1, lipoperoxides, and prostocyclin. Angiology 2002;53:279-85.

33. Shennan NM, Seed M, Wynn V. Variation in serum lipid and lipoprotein levels associated with changes in smoking behaviour in non obese Caucasian males. Atherosclerosis 1985;58:17-25.

34. Smith U. Carbohydrates, fat and insulin action. Am J Clin Nutr 1994;59:686-9.

35. Craig WY, Palomaki GE, Haddow JE. Cigarette smoking and serum lipid and lipoprotein

concentrations: an analysis of published data. $\mathrm{Br}$ Med J 1989;298:784-8.

36. Tell GS. Cigarette smoking, lipids, lipoproteins and extracranial carotid artery atherosclerosis. Mayo Clin Proc 1991;66:327-31.

37. Smilde TJ, van den Berkmortel FW, Wollersheim $\mathrm{H}$, van Langen $\mathrm{H}$, Kastelein JJ, Stalenhoef AFH. The effect of cholesterol lowering on carotid and femorial artery wall stifness and thickness in patients with familial hypercholesterolamia, Eur J Clin Invest 2000;30:473-80.

38. Varleta P, Concepción R, Vargas P, Casanova $\mathrm{H}$. Association of carotid intima-media thickness with traditional cardiovascular risk and metabolic factors. Rev Med Chil 2013;141:695-703.

39. Burgess JL, Kurzius-Spencer M, Gerkin RD, Fleming JL, Peate WF, Allison M. Risk factors for subclinical atherosclerosis in firefighters. J Occup Environ Med 2012;54:328-35. 
40. Morrow DA, Gersh BJ, Braunwald E. Chronic coronary artery disease. In: Zipes DP, Libby P, Bonow RO, Braunwald E, eds. Braunwald's Heart Disease. A Textbook of Cardiovascular Medicine. $7^{\text {th }}$ edition. Elsevier Saunders, Philadelphia, 2005.

41. Ross R, Glomset JA. Atherosclerosis and the arterial smooth muscle cell: proliferation of smooth muscle is a key event in the genesis of the lesions of atherosclerosis. Science 1973;180:1332-9.

42. Naylor AR, Mehta Z, Rothwell PM, Bell PR. Carotid artery disease and stroke during coronary artery bypass: a critical review of the literature. Eur J Vasc Endovasc Surg 2002;23:283-94. 